\title{
Factor B and C4b2a Autoantibodies in C3 Glomerulopathy
}

\author{
Jill J. Hauer, Dingwu Shao, Yuzhou Zhang, Carla M. Nester and Richard J. H. Smith* \\ Molecular Otolaryngology and Renal Research Laboratories, University of lowa, lowa City, IA, United States
}

C3 Glomerulopathy (C3G) is a renal disease mediated primarily by dysregulation of the alternative pathway of complement. Complement is the cornerstone of innate immunity. It targets infectious microbes for destruction, clears immune complexes, and apoptotic cells from the circulation, and augments the humoral response. In $\mathrm{C} 3 \mathrm{G}$, this process becomes dysregulated, which leads to the deposition of complement proteins-including complement component C3-in the glomerular basement membrane of the kidney. Events that trigger complement are typically environmental insults like infections. Once triggered, in patients who develop C3G, complement activity is sustained by a variety of factors, including rare or novel genetic variants in complement genes and autoantibodies that alter normal complement protein function and/or regulation. Herein, we review two such autoantibodies, one to Factor B and the other to C4b2a, the C3 convertase of the classical, and lectin pathways. These two types of autoantibodies are identified in a small fraction of C3G patients and contribute marginally to the C3G phenotype.

\section{OPEN ACCESS}

Edited by:

Bradley Patton Dixon,

Children's Hospital Colorado,

United States

Reviewed by:

Zoltan Prohaszka

Semme/weis University, Hungary

Anastasios E. Germenis,

University of Thessaly, Greece

*Correspondence:

Richard J. H. Smith

richard-smith@uiowa.edu

Specialty section:

This article was submitted to

Autoimmune and Autoinflammatory

Disorders,

a section of the journal

Frontiers in Immunology

Received: 01 November 2018

Accepted: 11 March 2019

Published: 04 April 2019

Citation:

Haver JJ, Shao D, Zhang Y, Nester CM and Smith RJH (2019) Factor B and C4b2a Autoantibodies in

C3 Glomerulopathy.

Front. Immunol. 10:668.

doi: 10.3389/fimmu.2019.00668
Keywords: complement dysregulation, autoantibodies, C3 glomerulopathies, factor B, C3 convertase, C5 convertase

\section{INTRODUCTION}

C3 Glomerulopathy $(\mathrm{C} 3 \mathrm{G})$ is an ultra-rare renal disease characterized by dysregulation of the alternative pathway (AP) of the complement cascade, which leads to the accumulation of complement cleavage products in the glomerular basement membrane (GBM) of the kidney. The complement cascade is comprised of over 30 proteins and can harness both the innate and adaptive immune systems to initiate and amplify an immune response in the presence of an antigen or unwanted cell debris. Activation occurs via three separate pathways: the classical, lectin, and alternative pathways. Classical pathway (CP) activation is mediated by the recognition of an antigen on a cell surface, the lectin pathway (LP) is initiated through the recognition of carbohydrates and other antigenic patterns, and the AP is spontaneously activated via the "tick-over" mechanism whereby an internal thioester bond of the $\mathrm{C} 3$ protein is hydrolyzed to form a functionally active form of the $\mathrm{C} 3$ protein $\left(\mathrm{C}_{3} \mathrm{H}_{20}\right)(1,2)$.

Once initiated, all pathways converge on the formation of the C3 convertase-an enzyme complex responsible for the amplification of the complement response-which rapidly cleaves and activates additional $\mathrm{C} 3$ protein. If complement activation is triggered through the $\mathrm{AP}$, the AP C3 convertase is formed by the interaction of cleaved $\mathrm{C} 3$ and Factor B proteins $(\mathrm{C} 3 \mathrm{bBb})$. In contrast, if CP or LP activation occurs, the classical C3 convertase is formed (C4b2a). Cleavage of C3 by C4b2a leads to formation of the AP C3 convertase, C3bBb, and over $90 \%$ of continued complement activity continues through this convertase (3). Robust $\mathrm{C} 3$ convertase activity generates copious $\mathrm{C} 3 \mathrm{~b}$ and facilitates the formation of the $\mathrm{C} 5$ convertase, which marks the beginning of the terminal complement cascade. C5 activation by the C5 convertase leads to the formation of the membrane attack complex (MAC), which is ultimately responsible for inducing lysis of the identified pathogen $(4,5)$. 
Rigorous regulation of complement is required to prevent unwanted complement activity. Cases of complement dysregulation lead to a diverse set of diseases underpinned by the common characteristic of damage to host tissue. C3 Glomerulopathy $(\mathrm{C} 3 \mathrm{G})$ is one such example (6-8). C3G is characterized by dysregulation of the AP, which leads to $\mathrm{C} 3$ deposition in the glomerulus. The diagnosis requires a renal biopsy, which by consensus must show by immunofluorescence the deposition of C3 in renal glomeruli that is at least 2-fold higher than any other immune reactant. Further categorization of C3G into subtypes is made by electron microscopy. If dense, intra-membranous, sausage-like deposits are seen, the diagnosis is dense deposit disease (DDD); when the deposits are lighter, cloud-like, and sub-epithelial, or sub-endothelial, the diagnosis is C3 Glomerulonephritis (C3GN) $(9,10)$. There is currently no disease-specific treatment for $\mathrm{C} 3 \mathrm{G}$ and about $50 \%$ of patients progress to end stage renal disease (ESRD) within 10 years of diagnosis (11).

The drivers of complement dysregulation in $\mathrm{C} 3 \mathrm{G}$ can be identified in the majority of cases and include genetic variants in complement proteins and regulators, and/or autoantibodies specific to proteins or complexes of the complement cascade. The earliest description of autoantibodies that target complement proteins dates back to 1967 when C3- and C4-targeting immunoglobulins were described in the serum of several species of mammals upon stimulation with the animal's autologous, fixed complement components (12). Subsequently, autoantibodies have been described in virtually every branch of the complement system: autoantibodies targeting CP proteins (13, 14), LP proteins (15), AP proteins (16), protein complexes including the C3 (17), and C5 (18) convertases, and complement regulatory $(19,20)$ proteins. Autoantibodies to complement can be detected in a diverse spectrum of diseases including systemic lupus erythematosus (SLE), rheumatoid arthritis (RA), atypical hemolytic uremic syndrome (aHUS), and C3G (21). This review is tightly focused on two types of autoantibodies that are specific for Factor B and C4b2a (also known as C4 nephritic factors or $\mathrm{C} 4 \mathrm{Nefs}$ ). We discuss the current knowledge relevant to these two antibodies, methods for their robust detection, and their more recently appreciated role in C3G (Figure 1).

\section{FACTOR B AUTOANTIBODIES}

Factor B autoantibodies (FBAAs) have been identified in a small number of individuals and exclusively in patients with C3G. The first report of FBAAs was in 2010-a DDD patient was positive for an IgG that bound the cleaved $\mathrm{Bb}$ fragment of Factor $\mathrm{B}$ and recognized an epitope on the $\mathrm{C} 3$ convertase $(\mathrm{C} 3 \mathrm{bBb})$. This antibody stabilized the $\mathrm{C} 3$ convertase and prevented its decay; it also prevented formation of the $\mathrm{C} 5$ convertase thereby inhibiting terminal pathway activity. Unlike the more common C3 nephritic factor, this FBAA did not bind a neoepitope on the C3 convertase and because it prevented terminal pathway activity, it tested negative in the hemolytic assay, which is traditionally used to detect the stabilizing effect of $\mathrm{C} 3$ nephritic factors (C3Nefs) on C3 convertase (16). In 2011, two more patients were reported to have FBAAs, which stabilized C3 convertase activity (22). All three patients were negative for C3Nefs $(16,22)$.
In a larger study on a cohort of 141 patients with C3G or Ig-associated membranoproliferative glomerulonephritis (immune complex glomerulonephritis, ICGN), seven patients were positive for FBAAs, three were positive for anti-C3b IgG, and five were positive for both FBAA and anti-C3b. Ten of these 15 patients were diagnosed with ICGN. Consistent with previous reports, the patients with FBAAs alone demonstrated specific enhancement of $\mathrm{C} 3 \mathrm{bBb}$ activity only; there was no enhancement of C5 convertase activity. Patients who were positive for both FBAAs and anti-C3b antibodies showed enhancement of both C3 and $\mathrm{C} 5$ convertase activity. FBAA binding was mapped to the $\mathrm{Bb}$ fragment of Factor B in this study (23).

Taken together, these data suggest that FBAAs are present in only a small percentage of the $\mathrm{C} 3 \mathrm{G}$ population and drive specific over-activity of C3 convertase. Factor B autoantibodies have not yet been associated with any other complementmediated diseases.

\section{C4 NEPHRITIC FACTORS}

In 1979, two patients with partial lipodystrophy were reported to have a nephritic factor the activity of which was dependent on the presence of $\mathrm{C} 2$, thus implicating the involvement of the classical C3 convertase, C4b2a (24). Shortly thereafter, C4Nef was fully characterized in a patient with post-infectious glomerulonephritis (PIGN) and proposed to be a separate entity from C3Nef. In this study, C4Nef was demonstrated to be an IgG capable of stabilizing both cell-bound and fluid-phase classical C3 convertase (25). Further investigation has shown that C4Nefs protect the classical $\mathrm{C} 3$ convertase from decay mediated by CR1 and $\mathrm{C} 4$ binding protein $(\mathrm{C} 4 \mathrm{BP})$ but not from decay mediated by decay accelerating factor (DAF) (26-29).

In 1989, a study of 2 patients diagnosed with MPGN type I detected the presence of both C3Nefs and C4Nefs. Both patients had low circulating levels of C3 and C5 proteins, consistent with complement consumption due to the presences of these Nefs (30). A case study in 1993 of 100 hypocomplementemic patients with MPGN found that almost $20 \%$ were positive for C4Nefs. Half of these patients were also positive for C3Nefs. Interestingly, terminal complement pathway activity was only elevated in patients positive for both C3Nefs and C4Nefs (31). Another case report described an 18-year-old male with C3 deficiency who developed severe meningococcal meningitis. C3 consumption was driven by $\mathrm{C} 4 \mathrm{Nefs}$, which stabilized both $\mathrm{C} 4 \mathrm{~b} 2 \mathrm{a}$ and $\mathrm{C} 4 \mathrm{~b} 2 \mathrm{aC} 3 \mathrm{~b}$, the $\mathrm{C} 5$ convertase of the classical pathway (32).

In aggregate, C4Nefs represent a possible cause of complement dysregulation in a small proportion of patients with complement-mediated diseases. Further studies are needed to elucidate their ability to stabilize both the C3 and C5 convertases of the classical pathway.

\section{DETECTION OF FBAA AND C4NEFS}

Autoantibody detection in C3G is generally performed using ELISA and hemolytic-based assays. Both FBAA and C4Nefs have been identified using ELISA assays $(23,33,34)$. For FBAAs, plates are coated with either the full length protein, the $\mathrm{Bb}$ fragment 


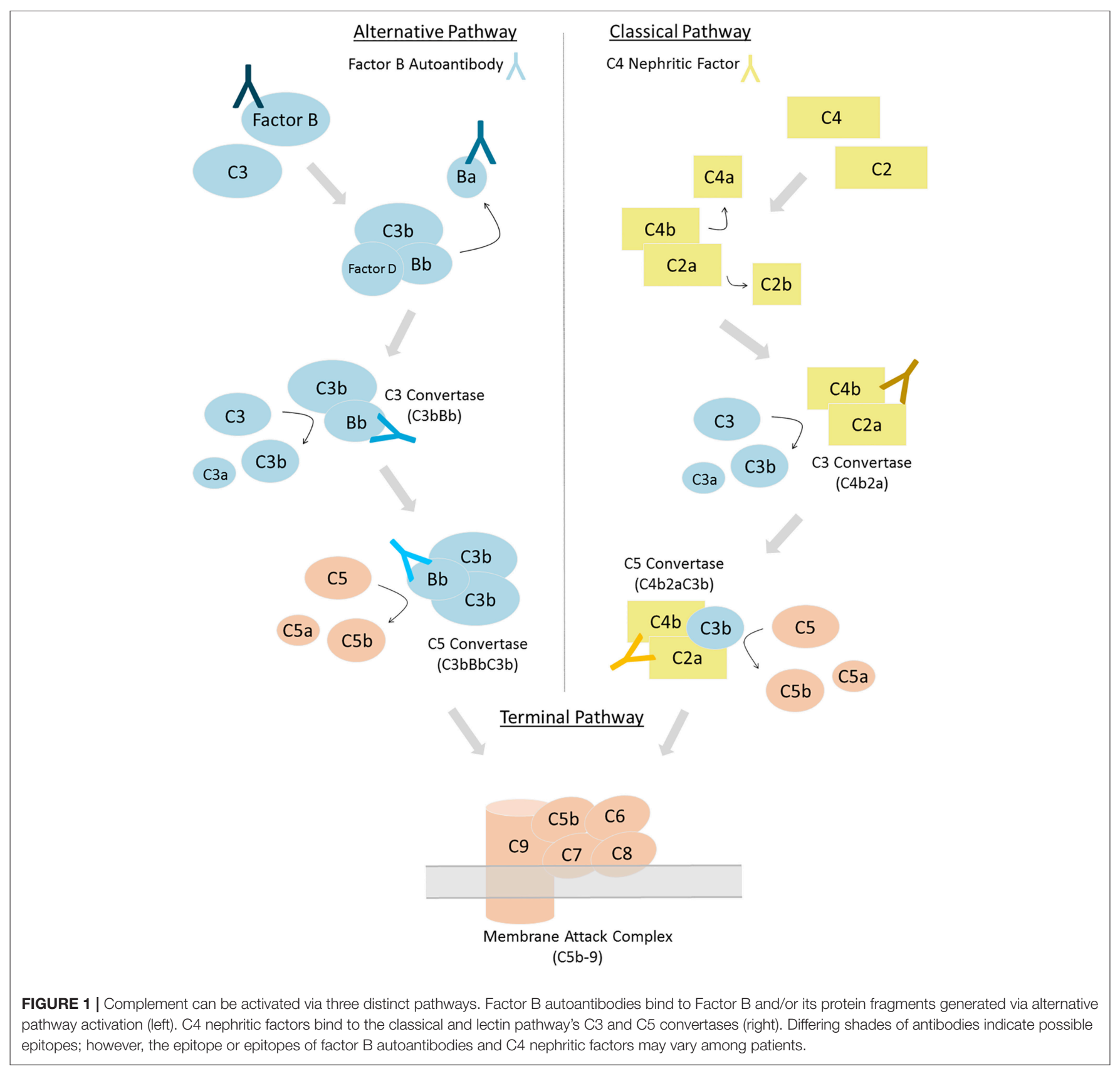

or the Ba fragment. After incubation with patient-purified IgG, binding can be detected using anti-human IgG (Figure 2A) (23). For C4Nef detection, a sandwich ELISA is used. This method indirectly detects $\mathrm{C} 4 \mathrm{Nefs}$ by detecting the increased stabilization of the C4b2a complex. To form the CP C3 convertase (C4b2a), patient IgG is added to normal human serum (NHS). After ample time is allowed for intrinsic decay of C4b2a, the NHS-IgG mix is added to a plate coated with anti-C2 antibodies. Convertases that have not decayed (i.e., that have been stabilized by C4Nefs) are detected using an anti-C4 antibody (33). Both methods test binding of the autoantibody to its target complement protein, however neither measures functional activity (Figure 2B).
The hemolytic assay uses sheep erythrocytes, which are non-complement activators, to measure hemolytic activity (35). To detect C4Nefs, C4b2a is first built on sheep erythrocytes that have been antibody primed, and then the C4b2a-coated erythrocytes are incubated with patient IgG. After a fixed time during which convertase decay occurs in the absence of C4Nefs or is prevented in their presence, terminal complement components are added and lysis is quantitated. The amount of free heme reflects the degree of convertase stabilization and activity $(33,36)$. This assay provides an environment closer to in vivo conditions (Figure 2C). 


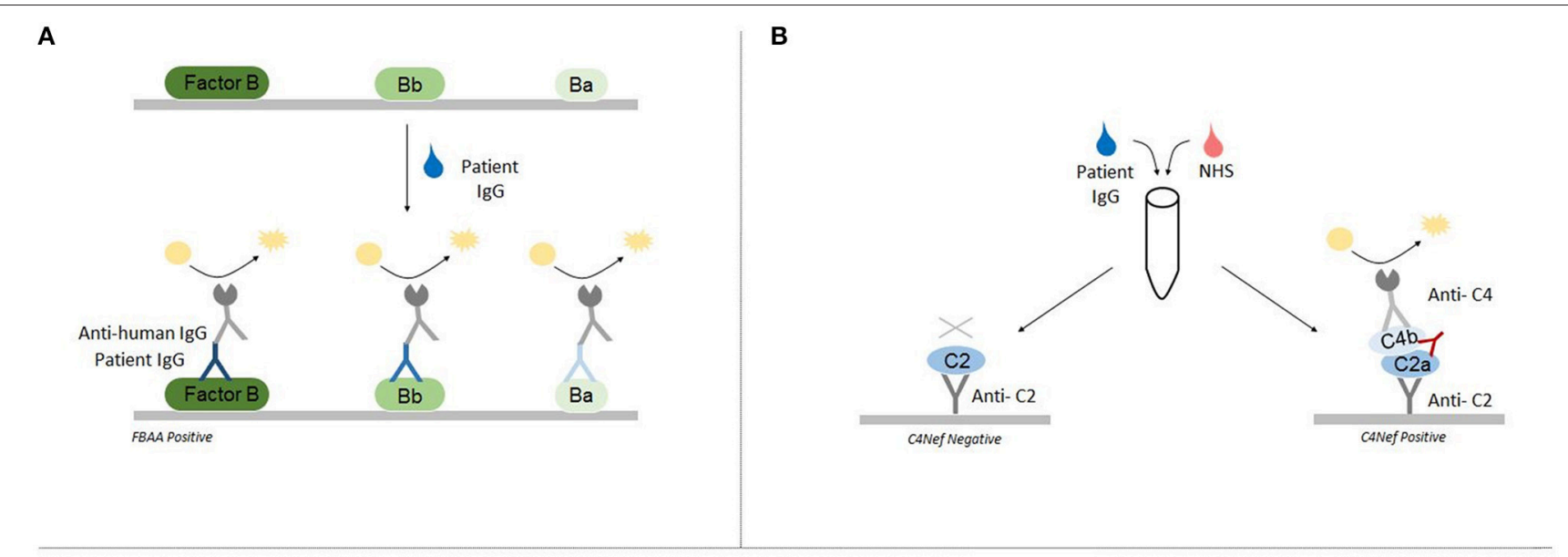

C

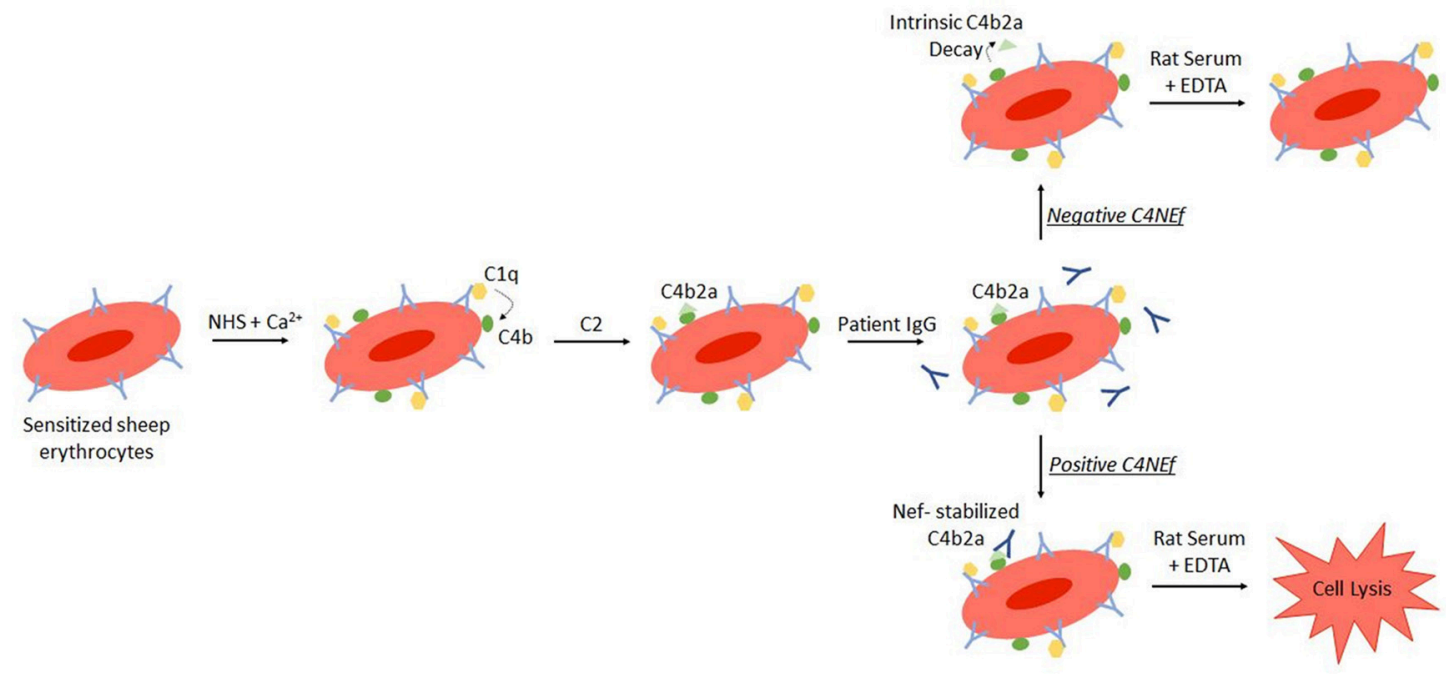

FIGURE 2 | Autoantibody detection is performed using ELISA-based and hemolytic-based assays. Factor B autoantibodies can be detected using an ELISA-based method (A). C4 nephritic factors can be detected using either a sandwich ELISA (B) or a hemolytic assay (C).

Most recently, Blom et al. developed a modified hemolyticbased method that is sensitive not only to Nefs but also to genetic abnormalities (37). The method uses full patient serum with the addition of a C5 inhibitor to build the convertase on sheep or rabbit erythrocytes. This method is able to determine if Nefs are resistant to the extrinsic decay of complement regulatory proteins in full patient serum $(36,38)$.

Each of the above assays has limitations that should be recognized and are summarized in Table $\mathbf{1}$.

\section{THE CONSEQUENCE OF FBAAS AND C4NEFS IN C3G}

Many types of autoantibodies can be detected in patients with C3G. In aggregate, autoantibodies that stabilize and increase the half-life of the $\mathrm{C} 3$ and $\mathrm{C} 5$ convertases (C3Nefs and C5nefs, respectively) are identified in $\sim 60 \%$ of patients (36, 39). Several studies have associated these autoantibodies with complement dysregulation, which supports the hypothesis that these autoantibodies are drivers of the C3G phenotype, although this relationship is not yet well understood.

Biomarker testing is often performed on sera from C3G patients to quantitate the degree of complement dysregulation. By measuring levels of circulating C3 and its cleavage products, for example, it is possible to identify when C3 convertase overactivity occurs. When low C3 levels (indicating C3 consumption, thus complement activation) are accompanied by low C5 and high soluble C5b-9 levels, dysregulation of both the C3 and C5 convertase is highly likely.

Data on the biomarker profile of $\mathrm{C} 3 \mathrm{G}$ patients with FBAAs are anecdotal. Marinozzi et al. identified three patients diagnosed with C3G who were positive for FBAAs. The biomarker profile of these three patients, and nine additional patients with ICGN showed only an increase in the Bb fragment of cleaved Factor B (data summarized in Table 2) (23). 
TABLE 1 | Methods for detection of Factor B autoantibodies and C4 nephritic factors.

\begin{tabular}{|c|c|c|c|}
\hline Method & Autoantibody & Strengths & Limitations \\
\hline $\begin{array}{l}\text { ELISA } \\
\text { (Figure 2A) }\end{array}$ & Factor B & $\begin{array}{l}\text { 1. Ability to map domain of lgG binding epitope by } \\
\text { coating ELISA plate with either } \mathrm{FB}, \mathrm{Bb} \text {, or } \mathrm{Ba} \\
\text { 2. Test is inexpensive and fast }\end{array}$ & $\begin{array}{l}\text { 1. Anti-human IgG is used to detect FBAA binding -this tests for } \\
\text { the presence of FBAA, but does not test the effect of FBAA on } \\
\text { complement function } \\
\text { 2. Assay is performed using patient purified IgG and is therefore unable } \\
\text { to test the effect of complement regulators on FBAA function } \\
\text { 3. Assay is performed on a protein-coated 96-well plate which does } \\
\text { not represent in vivo conditions }\end{array}$ \\
\hline $\begin{array}{l}\text { ELISA } \\
\text { (Figure 2B) }\end{array}$ & C4Nef & $\begin{array}{l}\text { 1. Assay is conducted with patient purified lgG and } \\
\text { normal human serum - this means nef function is } \\
\text { tested in the presence of complement regulatory } \\
\text { proteins } \\
\text { 2. Test is inexpensive and fast }\end{array}$ & $\begin{array}{l}\text { 1. Anti-C2 and anti-C4 are used to capture the classical convertase- } \\
\text { this means the presence of } \mathrm{C} 4 \mathrm{Nefs} \text { is indirectly tested, and does not } \\
\text { discern function of the classical convertase } \\
\text { 2. Assay is performed on a protein-coated } 96 \text {-well plate which does } \\
\text { not represent in vivo conditions }\end{array}$ \\
\hline $\begin{array}{l}\text { Hemolytic } \\
\text { (Figure 2C) }\end{array}$ & C4Nef & $\begin{array}{l}\text { 1. Assay is performed using sheep erythrocytes-a } \\
\text { more realistic representation of in vivo conditions } \\
\text { 2. Convertase function is directly quantified by } \\
\text { measuring hemolysis }\end{array}$ & $\begin{array}{l}\text { 1. Assay is technically difficult to perform } \\
\text { 2. Assay is performed using patient purified lgG and is therefore unable } \\
\text { to test the effect of complement regulators on FBAA function } \\
\text { 3. Assay does not discern where on the convertase the C4Nef } \\
\text { is binding }\end{array}$ \\
\hline
\end{tabular}

TABLE 2 | Biomarker profiles associated with Factor B autoantibodies and C4 nephritic factors.

\begin{tabular}{lll}
\hline Biomarker & FBAA (23) & C4Nef (40) \\
\hline C3 & Normal & Low \\
C3c & Not Tested & High \\
FB & Not Tested & Normal \\
Ba & Not Tested & Normal \\
Bb & High & Normal \\
C2 & Not Tested & Normal \\
C4 & Not Tested & Normal \\
C4a & Not Tested & Normal \\
C5 & Not Tested & Low \\
sC5b-9 & Normal & High \\
Properdin & Not Tested & Low \\
\hline
\end{tabular}

In the most recent case series of 168 patients with $\mathrm{C} 3 \mathrm{G}$, five were positive for C4Nefs using the hemolytic-based assay. Of note, two of the five patients positive for C4Nefs were also positive for other autoantibodies-one patient was positive for $\mathrm{C} 3 \mathrm{Nefs}$ and the other for Factor $\mathrm{H}$ autoantibodies. All five patients showed a biomarker profile consistent with dysregulation of the C3 and C5 convertase (findings summarized in Table 2) (40). These data are consistent with a study by Blom et al. who reported an individual with $\mathrm{C} 3 \mathrm{G}$ positive for C4Nefs (41).

\section{REFERENCES}

1. Janeway C, Travers P, Walport M, Shlomchik M. Immunobiology: The Immune System in Health And Disease. 5th ed. New York, NY: Garland Publishing (2001).

2. Gros P, Milder FJ, Janssen BJ. Complement driven by conformational changes. Nat Rev Immunol. (2008) 8:48-58. doi: 10.1038/nri2231

3. Harboe M, Ulvund G, Vien L, Fung M, Mollnes TE. The quantitative role of alternative pathway amplification in classical pathway induced

\section{CONCLUSIONS}

C3G is a complex disease, making a composite view of complement biomarkers and complement function, coupled with a genetic analysis and a thorough screen for autoantibodies essential in every patient. FBAAs and C4Nefs drive disease in a small fraction of patients. The small numbers of patients positive for these autoantibodies makes it difficult to discern the magnitude of their role as a disease driver, but as testing for these autoantibodies becomes routine, their impact will become better defined. More precise assays, which measure not only epitopes and function but also provide data on concentration and convertase avidity, are needed to better understand the nuanced impact of these autoantibodies on disease course and outcome.

\section{AUTHOR CONTRIBUTIONS}

$\mathrm{JH}, \mathrm{DS}, \mathrm{YZ}, \mathrm{CN}$, and RS contributed to the conception and design of the study. DS and YZ provided protocols for detection methods. JH performed the literature review. JH and RS wrote the manuscript. All authors contributed to manuscript revision, read, and approved the submitted version.

\section{FUNDING}

This work was supported in part by the National Institutes of Health R01 DK110023 to RS and CN and a National Science Foundation Graduate Research Fellowship 000390183 to JH. doi: 10.1111/j.1365-2249.2004.02627.x

4. Noris M, Remuzzi G. Overview of complement activation and regulation. Semin Nephrol. (2013) 33:479-92. doi: 10.1016/j.semnephrol.2013.08.001

5. Müller-Eberhard HJ. The killer molecule of complement. J Invest Dermatol. (1985) 85:47-52. doi: 10.1111/1523-1747.ep12275445

6. Liszewski MK, Java A, Schramm EC, Atkinson JP. Complement dysregulation and disease: insights from contemporary genetics. Annu Rev Pathol. (2017) 12:25-52. doi: 10.1146/annurev-pathol-012615-044145 
7. Zipfel PF, Skerka C, Hellwage J, Jokiranta ST, Meri S, Brade V, et al. Factor H family proteins: on complement, microbes and human diseases. Biochem Soc Trans. (2002) 30:971-8. doi: 10.1042/bst0300971

8. Nester CM, Smith RJ. Diagnosis and treatment of C3 glomerulopathy. Clin Nephrol. (2013) 80:395-403. doi: 10.5414/CN108057

9. Servais A, Noël LH, Frémeaux-Bacchi V, Lesavre P. C3 glomerulopathy. Contrib Nephrol. (2013) 181:185-93. doi: 10.1159/000348654

10. Fakhouri F, Frémeaux-Bacchi V, Noël LH, Cook HT, Pickering MC. C3 glomerulopathy: a new classification. Nat Rev Nephrol. (2010) 6:494-9. doi: 10.1038/nrneph.2010.85

11. Sethi S, Fervenza FC, Zhang Y, Zand L, Vrana JA, Nasr SH, et al. C3 glomerulonephritis: clinicopathological findings, complement abnormalities, glomerular proteomic profile, treatment, and follow-up. Kidney Int. (2012) 82:465-73. doi: $10.1038 / \mathrm{ki} .2012 .212$

12. Lachmann PJ. Conglutinin and immunoconglutinins. Adv Immunol. (1967) 6:479-527. doi: 10.1016/S0065-2776(08)60527-1

13. Agnello V, Koffler D, Eisenberg JW, Winchester RJ, Kundel HG. Clg precipitins in the sera of patients with systemic lupus erythematosus and other hypocomplementemic states: characterization of high and low molecular weight types. J Exp Med. (1971) 134:228s-41s.

14. He S, Lin YL. In vitro stimulation of $\mathrm{C} 1$ s proteolytic activities by $\mathrm{C} 1 \mathrm{~s}-$ presenting autoantibodies from patients with systemic lupus erythematosus. J Immunol. (1998) 160:4641-7.

15. Seelen MA, Trouw LA, van der Hoorn JW, Fallaux-van den Houten FC, Huizinga TW, Daha MR, et al. Autoantibodies against mannose-binding lectin in systemic lupus erythematosus. Clin Exp Immunol. (2003) 134:335-43. doi: 10.1046/j.1365-2249.2003.02274.x

16. Strobel S, Zimmering M, Papp K, Prechl J, Józsi M. Anti-factor B autoantibody in dense deposit disease. Mol Immunol. (2010) 47:1476-83. doi: 10.1016/j.molimm.2010.02.002

17. Spitzer RE, Vallota EH, Forristal J, Sudora E, Stitzel A, Davis NC, et al. Serum C'3 lytic system in patients with glomerulonephritis. Science. (1969) 164:436-7.

18. Daha MR, Kok DJ, Van Es LA. Regulation of the C3 nephritic factor stabilized C3/C5 convertase of complement by purified human erythrocyte C3b receptor. Clin Exp Immunol. (1982) 50:209-14.

19. Meri S, Koistinen V, Miettinen A, Törnroth T, Seppälä IJ. Activation of the alternative pathway of complement by monoclonal lambda light chains in membranoproliferative glomerulonephritis. J Exp Med. (1992) 175:939-50. doi: $10.1084 /$ jem.175.4.939

20. Geha RS, Quinti I, Austen KF, Cicardi M, Sheffer A, Rosen FS. Acquired C1-inhibitor deficiency associated with antiidiotypic antibody to monoclonal immunoglobulins. N Engl J Med. (1985) 312:534-40. doi: 10.1056/NEJM198502283120902

21. Dragon-Durey MA, Blanc C, Marinozzi MC, van Schaarenburg RA, Trouw LA. Autoantibodies against complement components and functional consequences. Mol Immunol. (2013) 56:213-21. doi: 10.1016/j.molimm.2013.05.009

22. Chen Q, Müller D, Rudolph B, Hartmann A, Kuwertz-Bröking E, Wu K, et al. Combined C3b and factor B autoantibodies and MPGN Type II. N Engl J Med. (2011) 365:2340-2. doi: 10.1056/NEJMc1 107484

23. Marinozzi MC, Roumenina LT, Chauvet S, Hertig A, Bertrand D, Olagne J, et al. Anti-factor B and anti-C3b autoantibodies in C3 glomerulopathy and Igassociated membranoproliferative GN. J Am Soc Nephrol. (2017) 28:1603-13. doi: 10.1681/ASN.2016030343

24. McLean RH, Nilson SH. C3 nephritic factor stabilization of the classic C3 convertase: a role for $\mathrm{C} 2$ in $\mathrm{C} 3$ nephritic factor activity. Proc Soc Exp Biol Med. (1979) 161:358-63. doi: 10.3181/00379727-161-40553

25. Halbwachs L, Leveillé M, Lesavre P, Wattel S, Leibowitch J. Nephritic factor of the classical pathway of complement: immunoglobulin G autoantibody directed against the classical pathway C3 convetase enzyme. J Clin Invest. (1980) 65:1249-56. doi: 10.1172/JCI109787

26. Daha MR, van Es LA. Relative resistance of the F-42-stabilized classical pathway C3 convertase to inactivation by C4-binding protein. J Immunol. (1980) 125:2051-4.

27. Gigli I, Sorvillo J, Mecarelli-Halbwachs L, Leibowitch J. Mechanism of action of the C4 nephritic factor. Deregulation of the classical pathway of C3 convertase. J Exp Med. (1981) 154:1-12. doi: 10.1084/jem.154.1.1
28. Fischer E, Kazatchkine MD, Mecarelli-Halbwachs L. Protection of the classical and alternative complement pathway C 3 convertases, stabilized by nephritic factors, from decay by the human C3b receptor. Eur J Immunol. (1984) 14:1111-4. doi: 10.1002/eji.1830141209

29. Ito S, Tamura N, Fujita T. Effect of decay-accelerating factor on the assembly of the classical and alternative pathway $\mathrm{C} 3$ convertases in the presence of $\mathrm{C} 4$ or C3 nephritic factor. Immunology. (1989) 68:449-52.

30. Tanuma Y, Ohi H, Watanabe S, Seki M, Hatano M. C3 nephritic factor and $\mathrm{C} 4$ nephritic factor in the serum of two patients with hypocomplementaemic membranoproliferative glomerulonephritis. Clin Exp Immunol. (1989) 76:82-5.

31. Ohi H, Yasugi T. Occurrence of $\mathrm{C} 3$ nephritic factor and $\mathrm{C} 4$ nephritic factor in membranoproliferative glomerulonephritis (MPGN). Clin Exp Immunol. (1994) 95:316-21. doi: 10.1111/j.1365-2249.1994.tb06530.x

32. Miller EC, Chase NM, Densen P, Hintermeyer MK, Casper JT, Atkinson JP. Autoantibody stabilization of the classical pathway C3 convertase leading to C3 deficiency and Neisserial sepsis: C4 nephritic factor revisited. Clin Immunol. (2012) 145:241-50. doi: 10.1016/j.clim.2012.09.007

33. Seino J, Kinoshita Y, Sudo K, Horigome I, Sato H, Narita M, et al. Quantitation of C4 nephritic factor by an enzyme-linked immunosorbent assay. J Immunol Methods. (1990) 128:101-8. doi: 10.1016/0022-1759(90)90468-B

34. Seino J, Fukuda K, Kinoshita Y, Sudo K, Horigome I, Sato H, et al. A new and specific enzyme-linked immunosorbent assay for the detection of $\mathrm{C} 3$ nephritic factor. Tohoku J Exp Med. (1985) 147:111-2. doi: 10.1620/tjem. 147.111

35. Rother U. A new screening test for C3 nephritis factor based on a stable cell bound convertase on sheep erythrocytes. $J$ Immunol Methods. (1982) 51:101-7. doi: 10.1016/0022-1759(82) 90386-6

36. Zhang Y, Nester CM, Martin B, Skjoedt MO, Meyer NC, Shao D, et al. Defining the complement biomarker profile of C3 glomerulopathy. Clin J Am Soc Nephrol. (2014) 9:1876-82. doi: 10.2215/CJN.01820214

37. Blom AM, Volokhina EB, Fransson V, Strömberg P, Berghard L, Viktorelius $\mathrm{M}$, et al. A novel method for direct measurement of complement convertases activity in human serum. Clin Exp Immunol. (2014) 178:142-53. doi: $10.1111 /$ cei.12388

38. Paixão-Cavalcante D, López-Trascasa M, Skattum L, Giclas PC, Goodship TH, de Córdoba SR, et al. Sensitive and specific assays for C3 nephritic factors clarify mechanisms underlying complement dysregulation. Kidney Int. (2012) 82:1084-92. doi: 10.1038/ki.2012.250

39. Daha MR, Fearon DT, Austen KF. C3 nephritic factor (C3NeF): stabilization of fluid phase and cell-bound alternative pathway convertase. J Immunol. (1976) 116:1-7.

40. Zhang Y, Meyer NC, Fervenza FC, Lau W, Keenan A, CaraFuentes G, et al. C4 nephritic factors in C3 glomerulopathy: a case series. Am J Kidney Dis. (2017) 70:834. doi: 10.1053/j.ajkd.2017. 07.004

41. Blom AM, Corvillo F, Magda M, Stasiłojć G, Nozal P, PérezValdivia MÁ, et al. Testing the activity of complement convertases in serum/plasma for diagnosis of C4NeF-mediated C3 glomerulonephritis. J Clin Immunol. (2016) 36:517-27. doi: 10.1007/s10875-0160290-5

Conflict of Interest Statement: RS is the director and $\mathrm{CN}$ is the associate director of the MORL, which offers testing of complement function in patients with ultra-rare complement -mediated renal diseases.

The remaining authors declare that the research was conducted in the absence of any commercial or financial relationships that could be construed as a potential conflict of interest.

Copyright $\odot 2019$ Hauer, Shao, Zhang, Nester and Smith. This is an open-access article distributed under the terms of the Creative Commons Attribution License (CC $B Y)$. The use, distribution or reproduction in other forums is permitted, provided the original author(s) and the copyright owner(s) are credited and that the original publication in this journal is cited, in accordance with accepted academic practice. No use, distribution or reproduction is permitted which does not comply with these terms. 